\title{
Layered Double Hydroxides Precursor as Chloride Inhibitor: Synthesis, Characterization, Assessment of Chloride Adsorption Performance
}

\author{
Lin Chi ${ }^{1,2,3}$, Zheng Wang ${ }^{1,2,3}$, Youfang Zhou ${ }^{1,2,3}$, Shuang Lu ${ }^{1,2,3, * \mathbb{C}}$ and Yan Yao ${ }^{4}$ \\ 1 School of Civil Engineering, Harbin Institute of Technology, Harbin 150001, China; \\ chilin8958@163.com (L.C.); wangz@163.com (Z.W.); 15692213712@163.com (Y.Z.) \\ 2 Key Lab of Structures Dynamic Behavior and Control of the Ministry of Education, Harbin Institute of \\ Technology, Harbin 150090, China \\ 3 Key Lab of Smart Prevention and Mitigation of Civil Engineering Disasters of the Ministry of Industry and \\ Information Technology, Harbin Institute of Technology, Harbin 150090, China \\ 4 China Building Materials Academy, Beijing 100024, China; yy@cnbm.com.cn \\ * Correspondence: lus@hit.edu.cn; Tel.: +86-132-146-000-50
}

Received: 22 November 2018; Accepted: 11 December 2018; Published: 13 December 2018

\begin{abstract}
In this study, the chloride adsorption behaviors of CaAl-Cl LDH precursors with various Ca:Al ratios were investigated. The optimal chloride ion removal rate was $87.06 \%$ due to the formation of hydrocalumite. The chloride adsorption products of $\mathrm{CaAl}-\mathrm{Cl} \mathrm{LDH}$ precursors were further characterized by X-ray diffraction analysis and atomic structure analysis, the adsorption mechanism was considered to be co-precipitate process. The chloride adsorption behaviors of cementitious materials blended with $\mathrm{CaAl}-\mathrm{Cl} \mathrm{LDH}$ precursors were further investigated. Leaching test according to Test Code for Hydraulic Concrete (SL352-2006) was performed to testify the stability of chloride ions in the mortar. The results show that more than $98.3 \%$ chloride ions were immobilized in cement mortar blended with CaAl-Cl LDH precursor and cannot be easily released again. The inhibition performance of steel in the electrolytes with/without CaAl LDH precursor was investigated by using electrochemical measurements. The results indicate that $\mathrm{CaAl} \mathrm{LDH}$ precursor can effectively protect the passive film on steel surface by chloride adsorption. Considering the high anion exchange capacities of the LDHs, synthesized chloride adsorbent precursor can be applied as new inhibitors blended in cementitious materials to prevent the chloride-induced deterioration. Moreover, the application of chloride adsorption on CaAl-Cl LDH could also be of interest for the application of seawater blended concrete.
\end{abstract}

Keywords: layered double hydroxides; chloride ion adsorption; corrosion inhibitor

\section{Introduction}

Concrete structures can be easily deteriorated by chloride and thus failed to serve the predetermined service lives in marine environments. The corrosion occurs when sufficient amounts of chloride ions have been accumulated onto the surface of the embedded steel. Generally, the aggression of chloride ions into the concrete is time consuming for the well protected concrete cover. To enhance the concrete properties, several kinds of inhibitors have been developed and applied in the practical engineering projects [1]. Such kind of inhibitors are usually presented as a thin and weak inertia film that are just attached on the surface of the steel bars to prevent chloride attack, correspondingly serious local corrosion will occur on the unprotected area. Comparatively, layered double hydroxides (LDHs) are found to be effective chloride adsorbents, effectively preventing chloride-induced deterioration in reinforced cementitious materials [2,3]. 
The hydrocalumite-like structure monosulfaluminate phases (AFm) with a stoichiometric formula of $\left.\left[\mathrm{Ca}_{2}(\mathrm{Al}, \mathrm{Fe})(\mathrm{OH})_{6}\right)\right] \cdot \mathrm{X} \cdot \mathrm{nH}_{2} \mathrm{O}$ have the highest chloride-binding capacity among the mainly hydration products (e.g., portlandite, ettringite, and tobermorite) of Portland cement, which can be classified into the wider LDH family. As a result of the reaction with the existing AFm phases, chloride ions are adsorbed and thus stabilized in the Friedel's salt. Nevertheless, the theoretical and practical amount of chloride by Cl-AFm phases are less than the synthetized LDH [4]. Since the experiment is not performed in a dilute solution, but a cement matrix, the effective binding capacity of AFm phases in the cement matrix becomes much less with the presence of other competitive anions in the pore solution. Nitrite type hydrocalumite is another synthetic LDH-like anion adsorbent that could absorb chloride ion effectively and release nitrite ions at the same time, which could be applied as a potential corrosion inhibitor $[5,6]$. Considering the high anion exchange capacities of the LDHs, Tatematsu and Sasaki [7] admixed LDHs phases in concrete as a chloride ions adsorbent. S. Yoon et al. showed that the use of calcined layered double hydroxides in cementitious materials can have extraordinary potential in preventing the chlorid-induced deterioration of the reinforced concrete [8].

Even though synthetized LDHs are effective absorbents that have a large chloride threshold level and can prevent chloride-induced deterioration in reinforced concrete, unfortunately it may slightly reduce the compressive strength [9]. Moreover, the amount of the synthesized LDH is quite limited for the large volume concrete in the construction project. Therefore, the ultra-high lime with aluminum process is a relative low cost and high effective method to synthesize CaAl LDH, by admixing lime and calcium aluminate in the chlorinated solution and precipitating with the chloride in the form of the calcium chloroaluminate $\left(\mathrm{Ca}_{4} \mathrm{Al}_{2} \mathrm{Cl}_{2}(\mathrm{OH})_{12}\right)[10,11]$. In addition, the chemical constitution of $\mathrm{CaAl} \mathrm{LDH}$ can be classified into $\mathrm{Cl}$-AFm phases, which is more compatible with the cement-based materials. However, synthesized chloride adsorbent precursor served as a new inhibitor blended in cementitious materials to prevent the chloride-induced deterioration is rarely mentioned. The purpose of this study was to synthesize and use hydrocalumite-precursor for efficient chloride sorption in aqueous media. The chloride sorption capacity was achieved by the formation of hydrocalumite. Furthermore, the $\mathrm{CaAl} \mathrm{LDH}$ precursor can be applied as a new-found chloride inhibitor blended in cementitious materials to prevent the chloride-induced deterioration or the application of seawater blended concrete.

\section{Materials and Methods}

\subsection{Synthesis of $\mathrm{CaAl}-\mathrm{Cl} \mathrm{LDH}$}

All chemicals used in this study are of analytical grade and deionized water is used all through the experiments. CaAl-Cl LDH was synthesized by ultra high lime with aluminate process (UHLA) method as reported elsewhere [10]. $\mathrm{Ca}(\mathrm{OH})_{2}$ (Aladdin, Shanghai, China), $\mathrm{NaAlO}_{2}$ (Aladdin, Shanghai, China), and $\mathrm{NaCl}$ (Aladdin, Shanghai, China) $\left(\left[\mathrm{Cl}^{-}\right]=0.24 \mathrm{~mol} / \mathrm{L}\right)$ with mole ratio $\mathrm{n}(\mathrm{Ca}: \mathrm{Al}: \mathrm{Cl})=$ 3:1:1, 3:2:1, 3:3:1, 3:4:1, 2:2:1 and 4:2:1 were mixed together and stirred at $300 \mathrm{rpm} 40{ }^{\circ} \mathrm{C}$ for $3.5 \mathrm{~h}$. Then, the synthesized CaAl-Cl LDH were separated by vacuum filtration. In order to remove the soluble impurities, the precipitate was further washed with deionized water and dried at $40{ }^{\circ} \mathrm{C}$ for $24 \mathrm{~h}$, finally ground into fine powder. The crystal structure of the precipitates was identified by $\mathrm{X}$-ray diffractometer (XRD, X'Pert PRO MPD, Malvern Panalytical Inc., Malvern, UK) in the range of $10^{\circ}$ to $90^{\circ}$ using $\mathrm{Cu}$ $\mathrm{K} \alpha$ radiation at $34 \mathrm{kV}$ and $20 \mathrm{~mA}$ and the scanning rate of $0.02^{\circ} / \mathrm{s}$. The chloride concentration in the filtrate was determined by Inductively Coupled Plasma-mass Spectrometry (XSeries II ICP-MS, Thermo Fisher Scientific Inc., Carlsbad, CA, USA). Chloride ions removal efficiency (R, \%) can be obtained from Equation (1):

$$
R=\frac{C_{\mathrm{o}}-C_{\mathrm{e}}}{C_{\mathrm{o}}} \times 100 \%
$$

where $C_{\mathrm{o}}$ and $C_{\mathrm{e}}$ represents the initial and final chloride concentration $(\mathrm{mg} / \mathrm{L})$ in the solution, respectively. 


\subsection{Chloride Adsorption Kinetics and Isotherms}

The CaAl Cl-LDH precursor is synthesized by the reaction interacted by $\mathrm{Ca}(\mathrm{OH})_{2}$ and $\mathrm{NaAlO}_{2}$ with the optimum $\mathrm{Ca} / \mathrm{Al}$ ratio, which have the $\mathrm{Cl}^{-}$ion absorbent capability. $\mathrm{NaCl}$ solutions $(0.12 \mathrm{~mol} / \mathrm{L}, 0.24 \mathrm{~mol} / \mathrm{L}$, and $0.48 \mathrm{~mol} / \mathrm{L})$ and the $\mathrm{CaAl}-\mathrm{Cl} \mathrm{LDH}$ precursors were mixed together to investigate the chloride adsorption kinetics [10]. At regular intervals (5 min, $10 \mathrm{~min}, 15 \mathrm{~min}, 20 \mathrm{~min}$, $25 \mathrm{~min}, 30 \mathrm{~min}, 1 \mathrm{~h}, 2 \mathrm{~h}$, and $3.5 \mathrm{~h}$ ), $3 \mathrm{~mL}$ supernatant was timely filtered and measured by ICP-MS for the analysis of $\mathrm{Cl}^{-}$concentration. The equilibrium chloride adsorption amount $Q_{\mathrm{e}}(\mathrm{mg} / \mathrm{g})$ is determined according to the Equation (2):

$$
Q_{\mathrm{e}}=\frac{\left(C_{\mathrm{o}}-C_{\mathrm{e}}\right) v}{m}
$$

where $m$ is the mass $(\mathrm{g})$ of the total mass of $\mathrm{Ca}(\mathrm{OH})_{2}$ and $\mathrm{NaAlO}_{2}$ and $V$ is the volume (L) of $\mathrm{NaCl}$ solution.

\subsection{Fixation Stability of Cement Mortar Blended with $\mathrm{NaCl}$ Solution}

Ordinary Portland cement (PO 42.5) in accordance with Chinese Standard GB175-2007 was used in this study [12]. Three binders were investigated. As shown in Table 1, for binder P1 and P2, NaCl solution $(0.12 \mathrm{~mol} / \mathrm{L})$ and desalinated water collected from the synthesis of $\mathrm{CaAl}-\mathrm{Cl} \mathrm{LDH}$ were used as the mixing water, respectively. For binder P3, synthesized CaAl precursors were blended in the cement mixture ( $5 \%$ of total cement mass). All samples were cast in molds $4 \times 4 \times 16 \mathrm{~cm}^{3}$. During the first $24 \mathrm{~h}$, all samples were kept in molds inside a climate chamber $\left(\mathrm{RH} 95 \%, 20{ }^{\circ} \mathrm{C}\right)$, then demolded and cured in a saturated lime water for 3 days and 28 days.

Table 1. Mix proportions of cement mortar $(\mathrm{g})$.

\begin{tabular}{cccccc}
\hline Binder & OPC & Sand & Absorb-Mixture & NaCl Solution & Desalinated Water \\
\hline P1 & 450 & 1350 & $/$ & 225 & $/$ \\
P2 & 450 & 1350 & $/$ & $/$ & 225 \\
P3 & 427.5 & 1350 & 22.5 & 225 & $/$ \\
\hline
\end{tabular}

Free chloride content was measured by the leaching method described in the Test Code for Hydraulic Concrete (SL352-2006) [13]. Firstly, cement mortar was crushed into small particles ( $<5 \mathrm{~mm}$ ). Secondly, $1.0 \mathrm{~g}$ sample together with $100 \pm 1 \mathrm{~mL}$ deionized water was added into a $250^{-} \mathrm{mL}$ beaker. Thirdly, the breaker was fixed onto the oscillators and vibrated for $1 \mathrm{~h}, 2 \mathrm{~h}, 3 \mathrm{~h}, 5 \mathrm{~h}, 7 \mathrm{~h}, 10 \mathrm{~h}, 15 \mathrm{~h}, 24 \mathrm{~h}$, and $30 \mathrm{~h}$. Fourthly, the solid components were extracted onto the membrane filter with $0.45 \mu \mathrm{m}$ sieve size via vacuum filtration method. Finally, the chloride content of the filtered extract was analyzed by using ICP measurement at 3 days and 28 days, respectively.

\subsection{Influence of Inhibitors on the Corrosion Behavior of Steel}

Carbon steel (Q235 steel bar, Ø10 mm, and L $90 \mathrm{~mm}$ ) with the composition of C $0.181 \%, \mathrm{Mn}$ $0.580 \%$, Si $0.350 \%$, S $0.023 \%$, P $0.012 \%$, and Fe $97.5 \%$ was used in this study. Detailed preparation of steel surface is described elsewhere [14]. The steel were ground with $\mathrm{SiC}$ paper from $100^{\#}, 400^{\#}, 1000^{\#}$, and $1200^{\#}$, then further polished with $\mathrm{Al}_{2} \mathrm{O}_{3}$ polishing powder, finally rinsed with acetone (Aladdin, Shanghai, China). Then, the steel was passivated in the saturated lime water and the ends of the steel connected with copper leads were coated with dense epoxy. The electrolytes are $3.5 \mathrm{wt} \% \mathrm{NaCl}$ $\left(\left[\mathrm{Cl}^{-}\right]=0.12 \mathrm{~mol} / \mathrm{L}\right)$ saturated $\mathrm{Ca}(\mathrm{OH})_{2}$ solution with and without $0.35 \mathrm{wt} \% \mathrm{CaAl} \mathrm{LDH}$ precursor.

The electrochemical measurements were performed by using the electrochemical workstation (Versa STAT 3F, Princeton Applied Research, Oak Ridge, TN, USA) with a typical three-electrode cell. The steel serves as the working electrode, saturated calomel electrode serves as the reference electrode and platinized titanium anode with a working area $1 \mathrm{~cm}^{2}$ serving as the counter electrode. The steel 
was immersed in the electrolytes for $30 \mathrm{~min}$ to achieve the state of open circuit potential (OPC) before the measurement. The testing frequency ranged from $10^{5}$ to $0.1 \mathrm{~Hz}$, and the $10 \mathrm{mV}$ amplitude of the sinusoidal cross-circuit was adopted. All the results of electrochemical testing are the average of three test runs.

\section{Results and Analysis}

\subsection{Synthesis of CaAl-Cl LDH with Various $n(C a: A l: C l)$ Ratio}

The formed mechanism of calcium chloroaluminate can be classified into two patterns: A direct chemical reaction among chloride, lime, and calcium aluminate, see Equation (3), and an indirect ion exchange between the $\mathrm{OH}^{-}$ions presented in the interlayers of $\mathrm{LDH}$ phase $\mathrm{Ca}_{4} \mathrm{Al}_{2}(\mathrm{OH})_{14}$ and unbounded chloride ions, see Equations (4) and (5) [8].

$$
\begin{gathered}
4 \mathrm{Ca}^{2+}+2 \mathrm{Al}(\mathrm{OH})_{4}{ }^{-}+2 \mathrm{Cl}^{-}+4 \mathrm{OH}^{-} \rightleftharpoons \mathrm{Ca}_{4} \mathrm{Al}_{2} \mathrm{O}_{6} \mathrm{Cl}_{2} \cdot 10 \mathrm{H}_{2} \mathrm{O} \\
4 \mathrm{Ca}^{2+}+2 \mathrm{Al}(\mathrm{OH})_{4}{ }^{-}+4 \mathrm{OH}^{-} \rightleftharpoons \mathrm{Ca}_{4} \mathrm{Al}_{2}(\mathrm{OH})_{14} \\
\mathrm{Ca}_{4} \mathrm{Al}_{2}(\mathrm{OH})_{14}+2 \mathrm{Cl}^{-} \rightleftharpoons \mathrm{Ca}_{4} \mathrm{Al}_{2} \mathrm{O}_{6} \mathrm{Cl}_{2} \cdot 10 \mathrm{H}_{2} \mathrm{O}+2 \mathrm{OH}^{-} \\
3 \mathrm{Ca}_{4} \mathrm{Al}_{2} \mathrm{O}_{6} \mathrm{Cl}_{2} \cdot 10 \mathrm{H}_{2} \mathrm{O}+2 \mathrm{Al}(\mathrm{OH})_{4}{ }^{-}+4 \mathrm{OH}^{-} \rightleftharpoons 4 \mathrm{Ca}_{3} \mathrm{Al}_{2}(\mathrm{OH})_{12}+6 \mathrm{Cl}^{-}+12 \mathrm{H}_{2} \mathrm{O} \\
3 \mathrm{Ca}(\mathrm{OH})_{2}+2 \mathrm{Al}(\mathrm{OH})_{3} \rightleftharpoons \mathrm{Ca}_{3} \mathrm{Al}_{2}(\mathrm{OH})_{12} \\
\mathrm{Ca}_{3} \mathrm{Al}_{2}(\mathrm{OH})_{12}+\mathrm{Ca}(\mathrm{OH})_{2}+6 \mathrm{H}_{2} \mathrm{O} \rightleftharpoons 2 \mathrm{Ca}_{2} \mathrm{Al}(\mathrm{OH})_{7} \cdot 3 \mathrm{H}_{2} \mathrm{O}
\end{gathered}
$$

Since the $\mathrm{CaAl} \mathrm{LDH}$ precursor is applied as the chloride inhibitor blended in the cementitious materials to prevent the chloride-induced deterioration. Saturated calcium hydroxide is the main ingredient in concrete pore solution and the $\mathrm{pH}$ is in range of 13-14 [15]. Many studies have been performed to determine the chloride threshold value leading the corrosion initiation [16-18]. The $\left[\mathrm{Cl}^{-}\right] /\left[\mathrm{OH}^{-}\right]$ratio is defined as the boundary limitation for corrosion occurrence, when the $\left[\mathrm{Cl}^{-}\right] /\left[\mathrm{OH}^{-}\right]$ratio higher than 0.6 , the corrosion occurs $[19,20]$. Therefore, $\mathrm{Ca}(\mathrm{OH})_{2}$ in the pore solution can create an alkaline environment for the interaction of $\mathrm{CaAl} \mathrm{LDH}$ precursor and chloride ions, and achieve the calcium hydroxides supplementation for dynamic equilibrium. Therefore, we adjusted several $\mathrm{Ca}: \mathrm{Al}: \mathrm{Cl}$ ratio for obtained the optimal $\mathrm{Ca}: \mathrm{Al}: \mathrm{Cl}$ ratio for cementitious materials system. The effect of $\mathrm{n}(\mathrm{Ca}: \mathrm{Al}: \mathrm{Cl})$ ratio on the chloride removal is shown in Table 2. The initial $\left[\mathrm{Cl}^{-}\right]$ concentration was $0.24 \mathrm{~mol} / \mathrm{L}$ and final $\mathrm{Cl}$ concentration was obtained by measuring chloride ions concentration remaining in the filtrate by ICP-MS, then the chloride ions removal efficiency $(\mathrm{R}, \%)$ can be obtained according to Equation (1). When $\mathrm{n}(\mathrm{Al} / \mathrm{Cl})=2$, the chloride adsorption rate is the most efficient among all $\mathrm{n}(\mathrm{Ca} / \mathrm{Cl})$ ratios. Additionally, with $\mathrm{n}(\mathrm{Al} / \mathrm{Cl})>2$, the chloride adsorption rate is generally decreased, which is mainly due to the precipitates formed in the first step could further react with the excessive $\mathrm{NaAlO}_{2}$ and then more soluble aluminum-chloride-hydroxide complexes will be formed in the solution [21]. Correspondingly, with $\mathrm{n}(\mathrm{Al} / \mathrm{Cl})=2, \mathrm{n}(\mathrm{Ca} / \mathrm{Cl})<2$, there is an obvious decrease in chloride adsorption rate, which is mainly due to the lack of calcium to react with the aluminum in the solution to form $\mathrm{LDH}$ phase $\mathrm{Ca}_{4} \mathrm{Al}_{2}(\mathrm{OH})_{14}$. Generally, if the formation of $\mathrm{LDH}$ phase $\mathrm{Ca}_{4} \mathrm{Al}_{2}(\mathrm{OH})_{14}$ is the only critical issue that affects the chloride adsorption, $\mathrm{n}(\mathrm{Al} / \mathrm{Cl})$ ratio should equal 2.0 and $\mathrm{n}(\mathrm{Ca} / \mathrm{Cl})$ should equal 3.0. This deviation of the observed efficiency from that expected for absorption of chloride should be caused by the formation of the other solid phase which will be discussed in detail below. Therefore, these results show that, in the case of chloride form of hydrocalumite, $\mathrm{n}(\mathrm{Ca}: \mathrm{Al}: \mathrm{Cl})=3: 2: 1$ is considered to be the optimal proportional and the chloride ions reduction was $87.06 \%$. 
Table 2. Ion concentration of filtrates by ICP-MS analysis.

\begin{tabular}{cccccc}
\hline $\mathbf{n}(\mathbf{C a}: \mathbf{A l : C l})$ & $\mathbf{p H}$ & $\mathbf{n}\left(\mathbf{C l}^{-}\right) \mathbf{g} / \mathbf{L}$ & $\mathbf{n}\left(\mathbf{A} \mathbf{l}^{3+}\right) \mathbf{g} / \mathbf{L}$ & $\mathbf{n}\left(\mathbf{C a}^{2+}\right) \mathbf{g} / \mathbf{L}$ & $\mathbf{R} \%$ \\
\hline $3: 1: 1$ & 12.65 & 1.707 & 0.400 & 0.053 & $79.96 \%$ \\
$3: 2: 1$ & 12.70 & 1.102 & 2.836 & 0.039 & $87.06 \%$ \\
$3: 3: 1$ & 12.67 & 1.511 & 5.839 & 0.049 & $82.27 \%$ \\
$3: 4: 1$ & 12.78 & 1.816 & 9.185 & 0.037 & $78.69 \%$ \\
$2: 2: 1$ & 12.66 & 1.807 & 3.579 & 0.032 & $78.79 \%$ \\
$4: 2: 1$ & 12.72 & 1.141 & 2.060 & 0.025 & $86.61 \%$ \\
\hline
\end{tabular}

To clarify the hypothesis discussed above, the chemical compositions of precipitations are identified by XRD analysis, see Figure 1. As shown in Figure 1, diffraction peaks of synthesized $\mathrm{CaAl}-\mathrm{Cl} \mathrm{LDH}$ with various $\mathrm{Ca} / \mathrm{Al}$ ratio are in good agreement with $\mathrm{Ca}_{3} \mathrm{Al}_{2}(\mathrm{OH})_{12}$ (JCPDS NO. 24-0217), $\mathrm{Ca}_{4} \mathrm{Al}_{2} \mathrm{O}_{6} \mathrm{Cl}_{2} \cdot 10 \mathrm{H}_{2} \mathrm{O}$ (JCPDS NO. 51-0045), $\mathrm{Ca}_{2} \mathrm{Al}(\mathrm{OH})_{7} \cdot 3 \mathrm{H}_{2} \mathrm{O}$ (JCPDS NO. 33-0255), and $\mathrm{Ca}(\mathrm{OH})_{2}$ (JCPDS NO. 04-0733). The diffraction peaks at $11.67^{\circ}$ corresponding to $\mathrm{Ca}_{4} \mathrm{Al}_{2} \mathrm{O}_{6} \mathrm{Cl}_{2} \cdot 10 \mathrm{H}_{2} \mathrm{O}$ is weakened with the excessive amount of $\mathrm{NaAlO}_{2}$. This is mainly due to the transformation of $\mathrm{Ca}_{4} \mathrm{Al}_{2} \mathrm{O}_{6} \mathrm{Cl}_{2} \cdot 10 \mathrm{H}_{2} \mathrm{O}$ into $\mathrm{Ca}_{3} \mathrm{Al}_{2}(\mathrm{OH})_{12}$, see Equation (6). In consequence, the chloride ions can be chemically released by the reaction with soluble $\mathrm{Al}(\mathrm{OH})_{4}{ }^{-}$. As for the excessive amount of $\mathrm{Ca}(\mathrm{OH})_{2}$, the diffraction peaks at $44.5^{\circ}$, corresponding to $\mathrm{Ca}_{3} \mathrm{Al}_{2}(\mathrm{OH})_{12}$, is weakened, which is due to the transformation of $\mathrm{Ca}_{3} \mathrm{Al}_{2}(\mathrm{OH})_{12}$ into $\mathrm{Ca}_{2} \mathrm{Al}(\mathrm{OH})_{7} \cdot 3 \mathrm{H}_{2} \mathrm{O}$, see Equations (7) and (8). According to the crystallinity calculation results by using JADE software, the calculated crystallinity of CaAl-Cl LDH with various $\mathrm{Ca}$ : $\mathrm{Al}$ : $\mathrm{Cl}$ ratios was determined and can be regarded as the semi-quantitative method for considering the optimal proportional for the formation of $\mathrm{CaAl}-\mathrm{Cl} \mathrm{LDH}$. According to the above discussion, $\mathrm{n}(\mathrm{Ca}): \mathrm{n}(\mathrm{Al}): \mathrm{n}(\mathrm{Cl})=3: 2: 1$ is considered to be the optimal proportion for the formation of CaAl-Cl LDH.
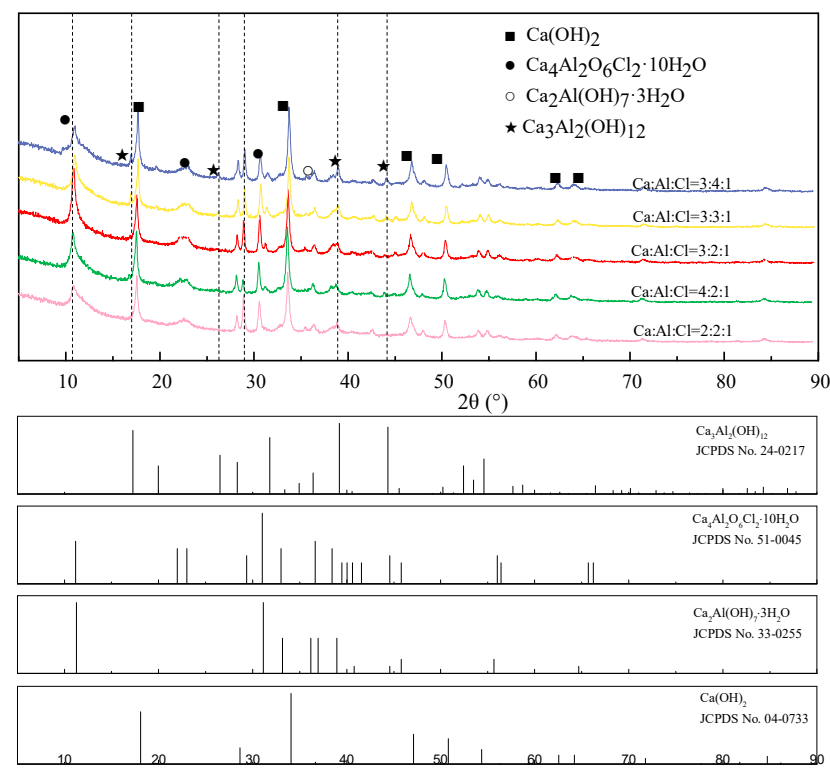

Figure 1. XRD patterns of precipitations after adsorption of chloride vs. various $\mathrm{n}(\mathrm{Ca}: \mathrm{Al}: \mathrm{Cl})$ ratios.

\subsection{Kinetic Study and Adsorption Isotherm}

The kinetics of $\mathrm{Cl}^{-}$adsorption by CaAl-Cl LDH precursors is shown in Figure 2. The results reveal that $\mathrm{CaAl}-\mathrm{Cl} \mathrm{LDH}$ precursors exhibits a higher adsorption rate (32-43\% chloride adsorbed) at the first $10 \mathrm{~min}$. Then, the adsorption rates slow down and tend to plat after $10 \mathrm{~min}$. Due to the chloride adsorption by $\mathrm{CaAl}-\mathrm{Cl} \mathrm{LDH}$ precursors belongs to the underlying mechanism of chemisorption. 
Therefore, the pseudo-second-order kinetic model depicted in Equation (9) is applied to characterize the adsorption process of the chloride adsorption process:

$$
\frac{d Q_{\mathrm{t}}}{d t}=k_{2}\left(Q_{\mathrm{e}}-Q_{\mathrm{t}}\right)^{2}
$$

where $Q_{\mathrm{e}}(\mathrm{mg} / \mathrm{g})$ is the chloride adsorbed capacity on the CaAl-Cl LDH precursors at equilibrium, $Q_{\mathrm{t}}(\mathrm{mg} / \mathrm{g})$ is the chloride adsorbed amount at time $\mathrm{t}, k_{2}\left(\mathrm{~g} / \mathrm{mg} \mathrm{min}^{-1}\right)$ is the second-order adsorption constant.

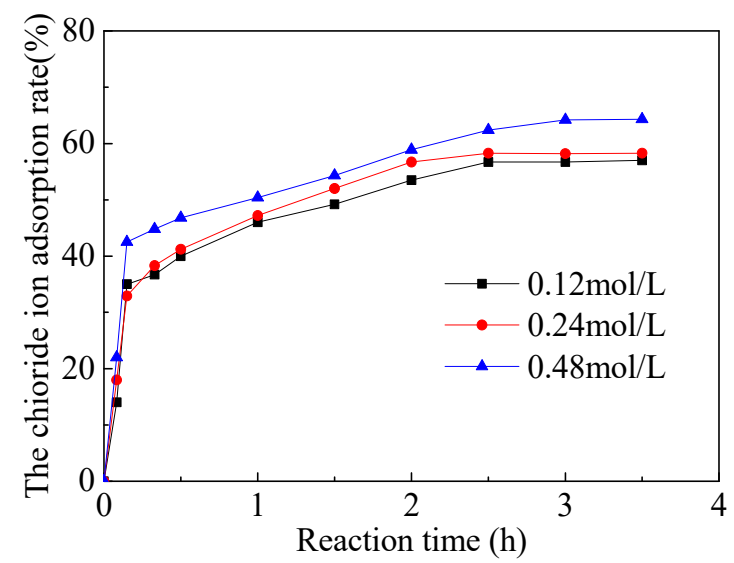

Figure 2. Effect of contact time on the adsorption of $\mathrm{Cl}^{-}$onto the CaAl-Cl LDH precursors with $\left[\mathrm{Cl}^{-}\right]=0.12 \mathrm{~mol} / \mathrm{L}, 0.24 \mathrm{~mol} / \mathrm{L}$ and $0.48 \mathrm{~mol} / \mathrm{L}$.

Equation (9) can be reduced to a simple formula as:

$$
\frac{t}{Q_{\mathrm{t}}}=\frac{1}{k_{2} Q_{\mathrm{e}}^{2}}+\frac{t}{Q_{\mathrm{e}}}
$$

The kinetic parameters and correlation coefficient $\left(R^{2}\right)$ are summarized in Table 3. The calculated adsorption capacities $\left(\mathrm{Cal}-\mathrm{Q}_{\mathrm{e}}\right)$ by using pseudo-second-order model are very close to the experimental values $\left(E x p-Q_{e}\right)$. The results indicate that pseudo-second-order model can be applied to describe the adsorption process of the chloride on CaAl-Cl LDH precursors.

Table 3. Comparison between the measured and estimated $Q_{\mathrm{e}}$ from the pseudo-second-order model.

\begin{tabular}{lcccc}
\hline & Exp$-Q_{\mathrm{e}}(\mathrm{mg} / \mathrm{g})$ & $\boldsymbol{k}_{\mathbf{2}}(\mathrm{g} / \mathrm{mg} \cdot \mathbf{m i n})$ & Cal- $_{\mathrm{e}}(\mathrm{mg} / \mathrm{g})$ & $\boldsymbol{R}^{\mathbf{2}}$ \\
\hline $0.12 \mathrm{~mol} / \mathrm{L}$ & 22.7 & 0.0030 & 23.1 & 0.9997 \\
$0.24 \mathrm{~mol} / \mathrm{L}$ & 22.2 & 0.0029 & 23.8 & 0.9979 \\
$0.48 \mathrm{~mol} / \mathrm{L}$ & 25.5 & 0.0024 & 25.7 & 0.9998 \\
\hline
\end{tabular}

Langmuir and Freundlich isotherm models are widely applied in the absorption process [22]. In this study, both models are comparatively adopted to analyze and explain the chloride absorption process, see Figure 3. Langmuir adsorption isotherm model is more fit for determining the adsorption rate and capacity of the monolayer chloride ions on the outer surface of the adsorbent, but failed to determine, if any, the further or other types of adsorption. The equilibrium distribution of ions from the solid to the liquid phases can be represented by the Langmuir model [23]:

$$
Q_{\mathrm{e}}=\frac{k_{\mathrm{L}} Q_{\mathrm{m}} C_{\mathrm{e}}}{1+k_{\mathrm{L}} C_{\mathrm{e}}}
$$


where $C_{\mathrm{e}}$ is the equilibrium mass concentration of the CaAl-Cl LDH precursors (mg/L), $Q_{\mathrm{m}}$ is the maximum adsorption amount of the chloride ion by CaAl-Cl $\mathrm{LDH}$ precursors $(\mathrm{mg} / \mathrm{g})$, and $k_{\mathrm{L}}$ is Langmuir isotherm constant (L/mg).

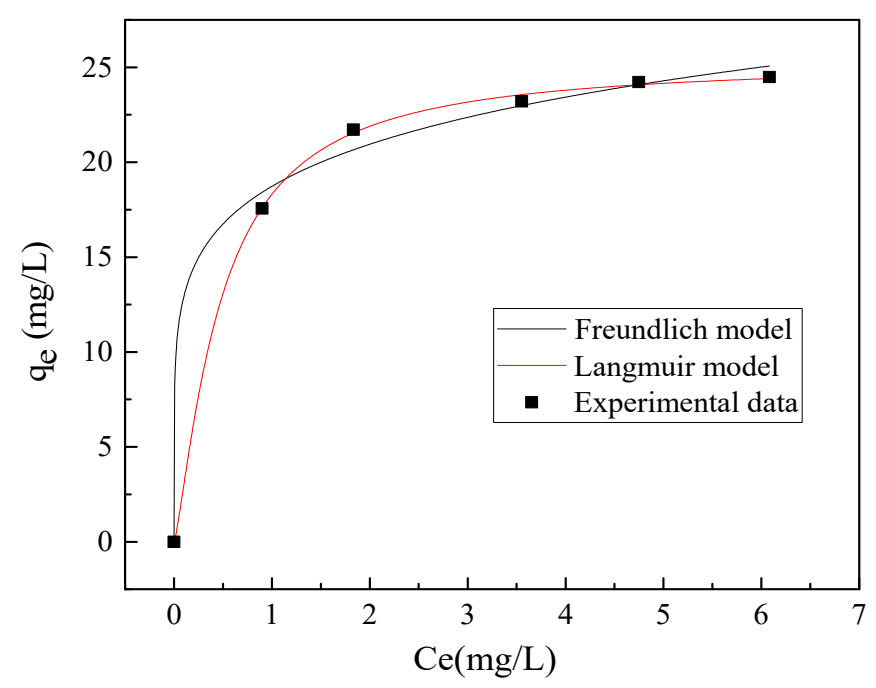

Figure 3. Isotherm for adsorption of chloride on CaAl-Cl LDH precursors.

Other than Langmuir model, Freundlich adsorption isotherm model Equation (12) is commonly used to describe the adsorption characteristic among the heterogeneous surfaces [24]:

$$
Q_{\mathrm{e}}=k_{\mathrm{F}} C_{\mathrm{e}}^{1 / \mathrm{n}}
$$

where $k_{F}$ is Freundlich isotherm constant $(\mathrm{mg} / \mathrm{g}), n$ is the adsorption intensity. $k_{F}$ and $\mathrm{n}$ could be determined by data fitting. The correlation coefficients $R^{2}$ of the Freundlich and Langmuir model are 0.907 and 0.989 , respectively. Langmuir adsorption isotherm is known as the formation process of a monolayer metal ions on the outer surface of the adsorbent, and Freundlich adsorption isotherm is usually applied to describe the adsorption characteristics of the heterogeneous surface [25]. Therefore, the chloride ions were adsorbed first on the LDH precursors edges, surface region, and then the interlayer space via diffusion [26,27]. Therefore, the Langmuir model is more suitable to describe the adsorption process of chloride ions on the CaAl LDH precursors.

Figure 4 presents the calculated structures of $\mathrm{CaAl} \mathrm{LDH}$ precursor and $\mathrm{CaAl}-\mathrm{Cl} \mathrm{LDH}$ visualized by Material studio. The cubic structure of $\mathrm{CaAl} \mathrm{LDH}$ precursor was presented as the 24-side deltoidal icositetrahedron from $\{010\}$ faces [28]. Furthermore, hydroxyl groups is served as a part of $\mathrm{Al}(\mathrm{OH})_{4}{ }^{-}$ groups in the bulk structures. However, with the adsorption of chloride ions by CaAl LDH precursor, it can be noticed that the atomic structure of $\mathrm{CaAl}-\mathrm{Cl} \mathrm{LDH}$ was shown as the layered crystals with octahedral structure as the skeleton and chloride ions as the interlayered anion from $\{110\}$ faces. The transformation of defined morphology to newly formed layered polyhedral structure is ascribed to as the molecular recognition between the crystal surfaces and the adsorption anions [28]. Taking the above analysis into account, the adsorption mechanism during the chloride ions adsorption process can be ascribed to the co-precipitation interacted between $\mathrm{Cl}^{-}$and the hydrolysis product of $\mathrm{CaAl}$ LDH precursors. 


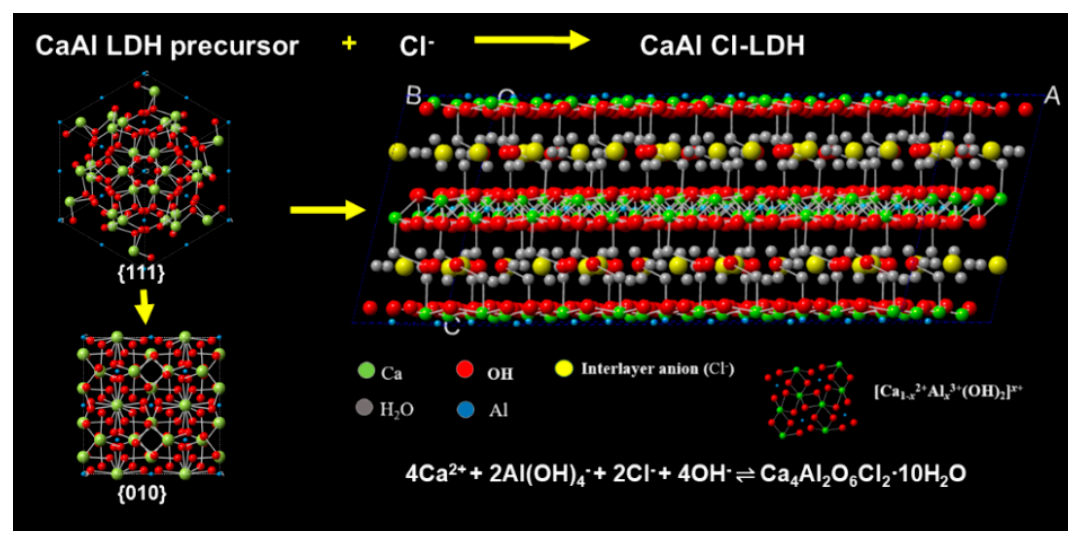

Figure 4. Calculated structures of $\mathrm{CaAl} \mathrm{LDH}$ precursor and CaAl-Cl LDH. Color key: Green, blue and yellow spheres represent $\mathrm{Ca}, \mathrm{Al}$ and $\mathrm{Cl}$ atoms, respectively. Red and grey spheres represent $\mathrm{H}_{2} \mathrm{O}$ and $\mathrm{OH}$ group.

\subsection{Chloride Leaching Test}

In order to testify the stability of chloride ions in the mortar, chloride ions leaching test was performed according to Test Code for Hydraulic Concrete (SL352-2006). Figure 5 shows the chloride immobilization rate in mortar P1, P2, and P3 at three days and 28 days, respectively. The results indicate that the chloride ions adsorption rate of mortar blended with $\mathrm{CaAl}-\mathrm{Cl} \mathrm{LDH}$ precursors is the highest. This is mainly due to the chloride ions could be captured by CaAl-Cl LDH precursors and then turn into CaAl-Cl LDH. Small gaps are presented between $\mathrm{P} 3$ at three days and 28 days, and $98.3 \%$ chloride ions have been immobilized in cementitious materials, which indicates chloride ions have been efficiently adsorbed by pre-blended CaAl-Cl LDH precursors in the early age and tiny parts of them will be further absorbed by the gradually formed cement hydration products. However, these further absorbed parts (Red region) will be easily released during the first $10 \mathrm{~h}$ leaching test period. The chloride ion leaching content of mortar P2 or P3 at 3d was higher than that of the same mortar at 28d. Correspondingly, the marked reduction of chloride ions adsorption rate P2 (Blue region) and P1 (Black region) indicates that chloride ions could be immobilized by the hydration products in the cement matrix [29]. The chloride binding mechanisms of the hydrated cement mortar have been summarized into two explanations. The chloride ions in the pore solution can easily enter into the interlayer space among the $\mathrm{C}-\mathrm{S}-\mathrm{H}$ gels and partly replace with $\mathrm{OH}^{-}$ions to maintain the charge balance [8,30-33]. Additionally, chemical reaction between the chloride ions and the AFm phases is another mechanism for chloride immobilization [34]. In particular, the AFm phase is a typical calcium derivative of double hydroxides (LDHs) family, which can adsorb chloride ions by forming CaAl-Cl $\mathrm{LDH}$. Therefore, it can be concluded that the mortar blended with CaAl-Cl LDH precursors could effectively prevent chloride ions ingress. This study provides additional theoretical and technical foundations for the feasibility of seawater mixing concrete. 


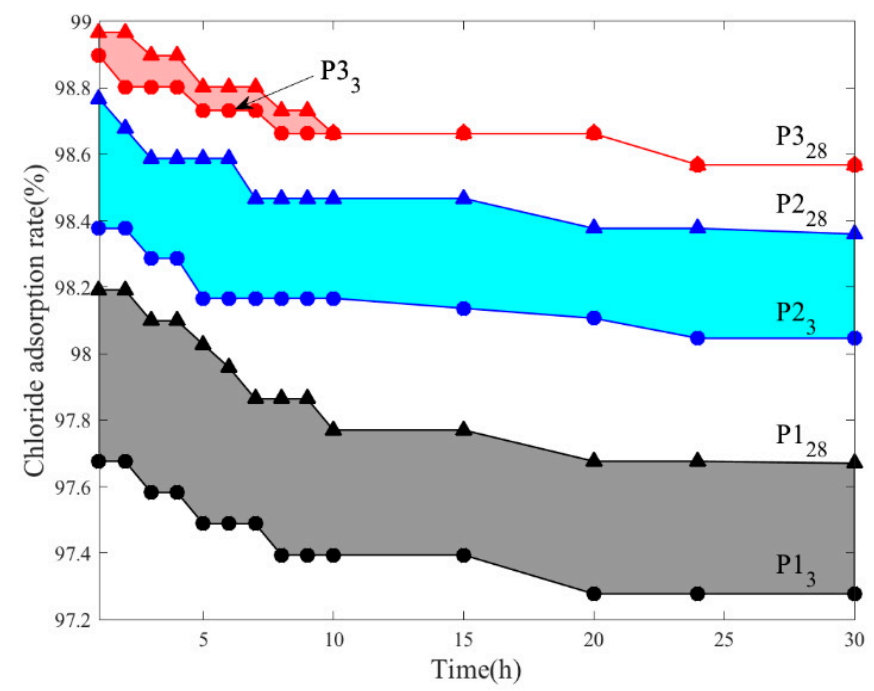

Figure 5. The chloride adsorption ratio of P1, P2, and P3 at 3d and 28d.

\subsection{Electrochemical Evaluation}

In the Figure 6, the surface of the sample immersed in reference system $(3.5 \% \mathrm{NaCl}$ saturated $\mathrm{Ca}(\mathrm{OH})_{2}$ solution without inhibitor) for $28 \mathrm{~d}$ is fully covered by ions rust. Correspondingly, the surface of the sample immersed in the system with inhibitor is still brightness. Therefore, electrochemical measurement by EIS test was performed to further evaluate the corrosion state of the steel. Figure 6a) is the impedance spectra plots of steel immersed in the reference system at $1 \mathrm{~d}$ and $28 \mathrm{~d}$. The initial impedance at $24 \mathrm{~h}$ is quite large. This is due to the passive film was formed on the surface of the steel in the saturated lime water [18]. However, there is a relative decrease of the diameter of semi-circle in the Nyquist plots at 28 days, which reveals the occurrence of corrosion activities on the surface of the steel [19]. This is mainly due to the protective film destroyed by forming soluble $\mathrm{FeCl}_{2}$. Correspondingly, Figure $6 \mathrm{~b}$ is the impedance spectra plots of steel immersed in the system with inhibitor at $1 \mathrm{~d}$ and $28 \mathrm{~d}$. And these two impedance spectra curves show identical electrochemical behaviors. This is due to the chloride ions adsorbed by $\mathrm{CaAl}-\mathrm{Cl} \mathrm{LDH}$ precursor by forming $\mathrm{CaAl}-\mathrm{Cl}$ $\mathrm{LDH}$ and consequently prevent the further corrosion. Therefore, it can be concluded that $\mathrm{CaAl}-\mathrm{Cl}$ $\mathrm{LDH}$ precursor can be served as an efficiently inhibitor hinders the corrosion actively.
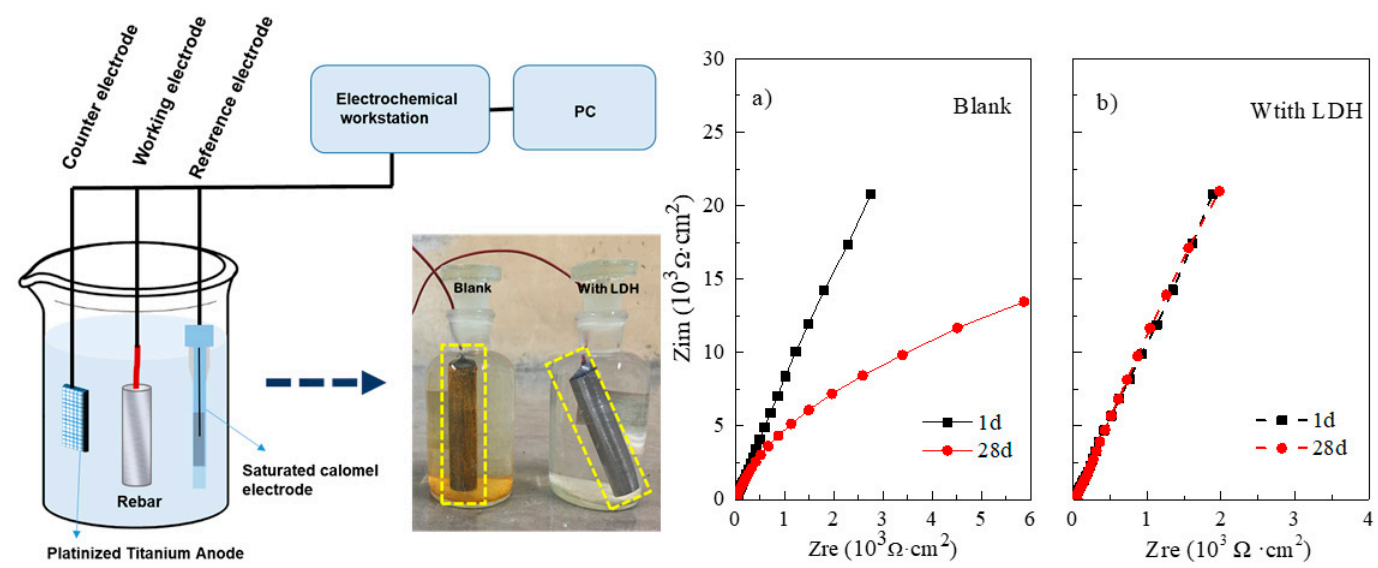

Figure 6. The schematic of the electrochemical (left); the corrosion state of steel bars immersed in two electrolytes after $28 \mathrm{~d}$ (middle); the impedance spectra plots of steel immersed in two electrolytes (with/without inhibitor) at $1 \mathrm{~d}$ and $28 \mathrm{~d}(\mathbf{a}, \mathbf{b})$. 


\section{Conclusions}

The following conclusions can be drawn based on the present laboratory investigation.

1. Chloride ions could be effectively adsorbed by $\mathrm{CaAl} \mathrm{LDH}$ precursor. The optimal chloride ion removal rate was $87.06 \%$ due to the formation of hydrocalumite with $\mathrm{Ca}: \mathrm{Al}: \mathrm{Cl}=3: 2: 1$.

2. The adsorption process could be well described by the pseudo-second-order model and Langmuir model. $98.3 \%$ chloride ions can be rapidly captured in cement mortar blended with CaAl-Cl LDH precursor and cannot be easily released again.

3. The inhibition performance of steel in the electrolytes with/without CaAl LDH precursor was investigated by using electrochemical measurements. The results indicates that $\mathrm{CaAl} \mathrm{LDH}$ precursor protect the passive film on steel surface by chloride adsorption.

4. This research indicates that $\mathrm{CaAl}-\mathrm{Cl} \mathrm{LDH}$ precursor is a potential and rapid adsorbent for immobilize chloride from sodium chloride water that prevents chloride-induced deterioration in reinforced concrete or mortar.

Author Contributions: Investigation, Writing-Original Draft Preparation, Visualization, Software, L.C.; Investigation, Formal Analysis, Y.Z.; Writing—Review \& Editing, S.L.; Supervision, Z.W., Y. Y.

Acknowledgments: The authors would like to appreciate the financial support of National Natural Science Foundation of China (Grant no. 51478150\&51872064).

Conflicts of Interest: The authors declare no conflict of interest. This article does not contain any studies with human participants or animals performed by any of the authors. Informed consent was obtained from all individual participants included in the study.

\section{References}

1. Soeylev, T.A.; Richardson, M.G. Corrosion inhibitors for steel in concrete: State-of-the-art report. Constr. Build. Mater. 2008, 22, 609-622. [CrossRef]

2. Auerbach, S.M.; Carrado, K.A.; Dutta, P.K. Handbook of Layered Materials, 4th ed.; CRC Press: New York, NY, USA, 2004.

3. Yao, J.; Kong, Q.; Zhu, H.; Long, Y.; Shen, D. Adsorption characteristics of nitrite on Friedel's salt under the landfill circumstance. Chem. Eng. J. 2014, 254, 479-485. [CrossRef]

4. Glasser, F.P.; Kindness, A.; Stronach, S.A. Stability and solubility relationships in AFm phases-Part 1. Chloride, sulfate and hydroxide. Cem. Concr. Res. 1999, 29, 861-866. [CrossRef]

5. Chen, Y.; Shui, Z.; Chen, W.; Chen, G. Chloride binding of synthetic Ca-Al-NO3 LDHs in hardened cement paste. Constr. Build. Mater. 2015, 93, 1051-1058. [CrossRef]

6. Xu, J.; Song, Y.; Zhao, Y.; Jiang, L.; Mei, Y.; Chen, P. Chloride removal and corrosion inhibitions of nitrate, nitrite-intercalated $\mathrm{Mg}$-Al layered double hydroxides on steel in saturated calcium hydroxide solution. Appl. Clay Sci. 2018, 163, 129-136. [CrossRef]

7. Tatematsu, H.; Sasaki, T. Repair materials system for chloride-induced corrosion of reinforcing bars. Cem. Concr. Comp. 2003, 25, 123-129. [CrossRef]

8. Yoon, S.; Moon, J.; Bae, S.; Duan, X.; Giannelis, E.P.; Monteiro, P.M. Chloride adsorption by calcined layered double hydroxides in hardened Portland cement paste. Mater. Chem. Phys. 2014, 145, 376-386. [CrossRef]

9. Birnin-Yauri, U.A.; Glasser, F.P. Friedel's salt, $\mathrm{Ca} 2 \mathrm{Al}(\mathrm{OH}) 6(\mathrm{Cl}, \mathrm{OH}) \cdot 2 \mathrm{H} 2 \mathrm{O}$ : Its solid solutions and their role in chloride binding. Cem. Concr. Res. 1998, 28, 1713-1723. [CrossRef]

10. Abdel-Wahab, A.; Batchelor, B. Chloride removal from recycled cooling water using ultra-high lime with aluminum process. Water Environ. Res. 2002, 74, 256-263. [CrossRef]

11. Abate, C.; Ssheetz, B.E. Aqueous phase equilibria in the system $\mathrm{CaO}-\mathrm{Al}_{2} \mathrm{O}_{3}-\mathrm{CaCl}_{2}-\mathrm{H}_{2} \mathrm{O}$ : The significance and stability of Friedel's salt. J. Am. Ceram. Soc. 1995, 78, 939-944. [CrossRef]

12. Chinese National Standard. Common Portland Cement; GB175-2007; Chinese National Standard: Beijing, China, 2007.

13. Chinese National Standard. Test Code for Hydraulic Concrete; SL 352-2006; Ministry of water resources of the People's Republic of China: Beijing, China, 2006. 
14. Liu, J.; Cai, J.; Shi, L.; Liu, J.; Zhou, X.; Mu, S.; Hong, J. The inhibition behavior of a water-soluble silane for reinforcing steel in $3.5 \% \mathrm{NaCl}$ saturated $\mathrm{Ca}(\mathrm{OH})_{2}$ solution. Constr. Build. Mater. 2018, 189, 95-101. [CrossRef]

15. Verbruggen, H.; Terryn, H.; De Graeve, I. Inhibitor evaluation in different simulated concrete pore solution for the protection of steel rebars. Constr. Build. Mater. 2016, 124, 887-896. [CrossRef]

16. Manera, M.; Vennesland, O.; Bertolini, L. Chloride threshold for rebar corrosion in concrete with addition of silica fume. Corros. Sci. 2008, 50, 554-560. [CrossRef]

17. Angst, U.; Elsener, B.; Larsen, C.K.; Vennesland, O. Critical chloride content in reinforced concrete-A review. Cem. Concr. Res. 2009, 39, 1122-1138. [CrossRef]

18. Liu, R.; Jiang, L.; Huang, G.; Zhu, Y.; Liu, X.; Chu, H.; Xiong, C. The effect of carbonate and sulfate ions on chloride threshold level of reinforcement corrosion in mortar with/without fly ash. Constr. Build. Mater. 2016, 113, 90-95. [CrossRef]

19. Figueira, R.B.; Sadovski, A.; Melo, A.P.; Pereira, E.V. Chloride threshold value to initiate reinforcement corrosion in simulated concrete pore solutions: The influence of surface finishing and $\mathrm{pH}$. Constr. Build. Mater. 2017, 141, 183-200. [CrossRef]

20. Geng, C.; Xu, Y.; Weng, D.; Wu, X. A time-saving method to determine the chloride threshold level for depassivation of steel in concrete. Constr. Build. Mater. 2010, 24, 903-909. [CrossRef]

21. Abdel-Wahab, A.; Batchelor, B.; Schwantes, J. An equilibrium model for chloride removal from recycled cooling water using the ultra-high lime with aluminum process. Water Environ. Res. 2005, 77, 3059-3065. [CrossRef]

22. Kano, F.; Abe, I.; Kamaya, H.; Ueda, I. Fractal model for adsorption on activated carbon surfaces: Langmuir and Freundlich adsorption. Surf. Sci. 2000, 467, 131-138. [CrossRef]

23. Langmuir, I. The adsorption of gases on plane surfaces of glass, mica and platinum. J. Am. Chem. Soc. 1918, 40, 1362-1403. [CrossRef]

24. Baseri, H.; Tizro, S. Treatment of nickel ions from contaminated water by magnetite based nanocomposite adsorbents: Effects of thermodynamic and kinetic parameters and modeling with Langmuir and Freundlich isotherms. Process Saf. Environ. 2017, 109, 465-477. [CrossRef]

25. Chi, L.; Wang, Z.; Sun, Y.; Lu, S.; Yao, Y. Crystalline/Amorphous Blend Identification from Cobalt Adsorption by Layered Double Hydroxides. Materials 2018, 11, 17069. [CrossRef] [PubMed]

26. Roeffaers, M.B.; Sels, B.F.; Loos, D.; Kohl, C.; Müllen, K.; Jacobs, P.A. In situ space- and time-resolved sorption kinetics of anionic dyes on individual ldh crystals. Chem. Phys. Chem. 2010, 6, 2295-2299. [CrossRef] [PubMed]

27. Chi, L.; Wang, Z.; Sun, Y.; Lu, S.; Yao, Y. Removal of cobalt ions from waste water by Friedel's salt. Mater. Res. Express 2019, 6, 015508. [CrossRef]

28. Fogg, A.M.; Freij, A.J.; Rohl, A.L.; Ogden, M.I.; Parkinson, G.M. Toward a fundamental understanding of molecular recognition: A synthetic and computational study of morphological control of $\mathrm{Ca}_{3} \mathrm{Al}_{2}(\mathrm{OH})_{12}$. J. Phys. Chem. B 2002, 106, 5820-5826. [CrossRef]

29. Glasser, F.P.; Marchand, J.; Samson, E. Durability of concrete-Degradation phenomena involving detrimental chemical reactions. Cem. Concr. Res. 2008, 38, 226-246. [CrossRef]

30. Beaudoin, J.J.; Ramachandran, V.S.; Feldman, R.F. Interaction of chloride and C-S-H. Cem. Concr. Res. 1990, 20, 875-883. [CrossRef]

31. Yoon, S.; Ha, J.; Chae, S.R.; Kilcoyne, D.A.; Monteiro, P.J.M. X-ray spectromicroscopic study of interactions between $\mathrm{NaCl}$ and calcium silicate hydrates. Mag. Concrete Res. 2014, 66, 141-149. [CrossRef]

32. Matschei, T.; Lothenbach, B.; Glasser, F.P. The AFm phase in Portland cement. Cem. Concr. Res. 2007, 37, 118-130. [CrossRef]

33. Marinescu, M.V.A.; Brouwers, H.J.H. Estimation of chloride contents in hardened OPC pastes. In Proceedings of the 3rd International RILEM Conference on Modelling the Durability of Reinforced Concrete, Guimaraes, Portugal, 22-24 October 2009; pp. 22-24.

34. Suryavanshi, A.K.; Scantlebury, J.D.; Lyon, S.B. Mechanism of Friedel's salt formation in cements rich in tri-calcium aluminate. Cem. Concr. Res. 1996, 26, 717-727. [CrossRef] 